\title{
Corporate Governance of Capital Market of Bangladesh
}

\author{
Md. Siraz Meah. Lecturer \\ Faculty of Business Administration. Department of Finance \& Banking BGC Trust University Bangladesh, \\ Bangladesh
}

\begin{abstract}
This paper outlines the conceptual, contextual and disciplinary scope of the rapidly evolving area of corporate governance of capital market of Bangladesh. As a basis for improving the rigor of research and analysis, some definitions, principles, theories and legal frame work of corporate governance are examined. This study also investigates the extent to which the capital market of Bangladesh comply with the corporate governance guidelines of Securities and Exchange Commission Bangladesh(SECB) and it also indicates that only sound corporate governance practices are the foundation upon which the trust of investors(stakeholders, banks, and non bank financial institutions) and other stakeholders is founded.
\end{abstract}

Key words: Corporate governance, capital market of Bangladesh, SECB

\section{Introduction}

Corporate governance implies that the company would manage its affairs with diligence, transparency, responsibility, and accountability and would maximize the shareholders wealth[1].According to the Rossenberg defined[2]"corporate governance as a blend of law ,regulation, enforcement and appropriate voluntary practices by companies that permit a company to attract the capital market perform efficiently, and generate long term value for its stakeholders, while respecting the interests of stakeholders and society as a whole". There is a significant body of theoretical and empirical literature in accounting and finance that considers the relation among corporate governance, management turnover, corporate performance, corporate capital structure and corporate ownership structure [3]. According to the Aslam and Mamun(2005) "The degree of closeness of managers stockholders relationship has a significance influence on the governance of the companies". OECD[4] Adhoc Taskforce on Corporate Governance (1998) defined corporate governance as "a set of relationship between a company's management; its board, its shareholders". So Corporate Governance should provide proper incentives for the board and management to pursue the objectives that are in the interest of the company and shareholders. To make good governance a reality, what is needed is a combination of visionary policies and bold actions.

\section{Objectives of the study}

This study emphasizes on corporate governance that will be practiced in the capital market of Bangladesh. The study includes the following objectives:

i) To focus on the corporate governance principles, theories etc

ii) To know the status of corporate governance of capital market of Bangladesh.

iii) To evaluate the legal process under which corporate governance of capital market of Bangladesh is being regulated.

\section{Principles of corporate governance}

Contemporary discussions of corporate governance tend to refer to principles raised in three documents released since 1990: The Cadbury Report (UK.1992), the Principles of Corporate Governance (OECD, 1998 and 2004), the Sarbanes-Oxley Act of 2002 (US, 2002).The Cadbury and OECD reports present general principles around which businesses are expected to operate to assure proper governance. The Sarbanes-Oxley Act, informally referred to as Sarbox of Sox, is an attempt by the federal government in the United States to legislate several of the principles recommended in the Cadbury and OECD reports. These internationally agreed principles consist of the following:

4.1 Right and equitable treatment of shareholders: Organization should respect the rights of shareholders and help shareholders to exercise those rights. They can help shareholders exercise their rights by openly and effectively communicating information and by encouraging shareholders to participate in general meetings.

4.2 Interest of other stakeholders: Organization should recognize that they have legal, contractual, social, and market driven obligations to non - shareholder stakeholders, including employees, investors, creditors, suppliers, local communities, customers, and policy makers. 
4.3 Role and responsibilities of the board: The board needs sufficient relevant skills and understanding to review and challenge management performance. It also needs adequate size and appropriate levels of independence and commitment.

4.4 Integrity and ethical behavior: Integrity should be a fundamental requirement in choosing corporate officers and board members. Organizations should develop a code of conduct for their directors and executives that promote ethical and responsible decision making.

4.5 Disclosure and transparency: Organizations should clarify and make publicly known the roles and responsibilities of board and management to provide stakeholders with a level of accountability. They should also implement procedures to independently verify and safeguard the integrity of the company's financial reporting. Disclosure of material matters concerning the organization should be timely and balanced to ensure that all inventors have access to clear, factual information.

\section{Theories relevant to corporate governance}

Hawley \&Williams (1996) undertook a literature review of corporate governance in the US as a background paper for the Organization for Economic Corporation and Development (OECD).They identified four models of corporate control: 1.The Simple Finance Model; 2.The Stewardship Model; 3.The Stakeholder Model; and 4.The Political Model.

5.1 The Simple Finance Model: 'In the finance view, the central problem in corporate governance is to construct rules and incentives (that is, implicit or explicit 'contracts') to effectively align the behavior of managers (agents) with the desires of principals (owners)' [5]. The rules and incentives in finance model refer to those established by the firm rather than to the legal/political/regulatory system and culture of the host economy or the nature of the owners.

5.2 The Stewardship Model: In the Stewardship model, 'managers are good stewards of the corporations and diligently work to attain high levels of corporate profit and shareholders return' [6].Their arguments support the investment of business schools and their students in the development of management skills and knowledge. Donaldson and Davis note that 'Managers are principally motivated by achievement and responsibility needs' and 'given the needs of managers for responsible, self-directed work organizations may be better served to free managers from subservience to non-executive director dominated boards'. Board can become redundant when there is a dominant active shareholder, especially when the major shareholder is a family or government.

5.3 The stakeholder model: In defining 'Stakeholder Theory' Clarkson (1994) states: "The firm" is a system of stakeholders operating within the larger system of the host society that provides the necessary legal and market infrastructure for the firm's activities. The purpose of the firm is to create wealth or value for its stakeholders by converting their stakes into goods and services. Both stakeholder voice and ownership, as suggested by Porter and Blair, could be provided by ' re-inventing' the concept of a firm as proposed by Turnbull[7].The proposal is based on tax incentives providing.

5.4 The political model: The political model recognizes that the allocation of corporate power, privileges and profits between owners, managers and other stakeholders is determined by how government favor their various constituencies. The ability of corporate stakeholders to influence allocations between themselves at the micro level is subject to the macro frame work, which is interactively subjected to the influence of the corporate sector. However, Hawley \& Williams focus their discussion only on the micro aspects of how shareholders can influence firms. They also focused on the micro level of the political model as articulated by Gundfest[8] and Pound. Pound defined the 'political model of governance' as an approach, 'in which active investors seek to change corporate policy by developing voting support from dispersed shareholders, rather than by the simply purchasing voting power or control'.

\section{Capital market \& Corporate Governance of Bangladesh}

A capital market is a market for securities (debt or equity), where business enterprises (companies) and governments can raise long-term funds. It is defined as a market in which money is provided for periods longer than a year[9] as the raising of short-term funds takes place on other markets (e.g., the money market). The capital market includes the stock market (equity securities) and the bond market (debt). Financial regulators oversee the capital markets in their designated jurisdictions to ensure that investors are protected against fraud, among other duties. Capital markets may be classified as primary markets and secondary markets. In primary markets, new stock or bond issues are sold to investors via a mechanism known as underwriting. In the secondary markets, existing securities are sold and bought among investors [10] or traders, usually on a securities exchange, over-the-counter, or elsewhere.

A strong capital market is a powerful indicator of economic development of a country. The good functioning of the capital market is vital in the contemporary economy, in order to achieve an efficient transfer of monetary resources from those who save money toward those who need capital and who succeed to offer it a 
superior utilization; the capital market can influence significantly the quality of investment decisions. In addition, the capital market mechanism allows not only an efficient allocation of the financial resources available at a certain moment in an economy [11]-from the market's point of view-but also permits to allot funds according the return and the risk-from the investor's point of view-offering a large variety of financial instruments with different profitableness-risk characteristics, suitable for saving or risk covering.

It is well funded the observation that in developing countries we should pay the same attention to the set up and development of an efficient capital market, in the same way in which there are preoccupations for the infrastructure or telecommunications' development[12]. This thing becomes more important in the transitional countries, taking into account the necessity of resources reorientation from the inefficient sectors towards the efficient ones, being thus ensured the increasing efficiency in economy, being supported both the economic reform process and the privatization process.

\section{Capital market of Bangladesh}

As developing economy, Bangladesh has a long and illustrious history of its capital market development. On April 28, 1954 during the Pakistan regime the DSE was first incorporated under the East Pakistan Stock Exchange Association Limited and formal trading began in 1956 with 196 securities listed with the DSE. Since then the capital market of Bangladesh is gradually endeavoring to emerge as a vibrant and giant player of the country's economy. The Dhaka Stock Exchange is a non-profit organization. It has a 24 members Council of which 12 are elected from the exchange members and 12 are nominated from the non-exchange members by the elected exchange member-councilors, subject to the approval of SECB. The executive power of DSE is vested in the chief executive officer (CEO) and under the leadership of CEO the executive body conducts the daily affairs of DSE. The board of directors of DSE appoints the CEO with the approval of SECB.

On the other hand, Chittagong was missing one very important element of an industrialized economy a stock exchange, which is an indispensable vehicle to channel funds to the entrepreneurs. Business Leaders of Chittagong felt the need, and also realized that the only Dhaka Stock Exchange (DSE) is not enough to meet the primary objective of having an exchange. In the backdrop of the scenario CSE was established in 1995.It is a public limited company. It has started trading on October 10, 1995. The Chittagong Stock Exchange is also a non-profit organization and formation of the board of directors, size and the rules of election of directors are also similar to DSE. The executive power of CSE is also vested in the CEO, and the executive body conducts the daily affairs of the exchange. The CEO is appointed by the Board with the approval of him Commission.

Now CSE pioneered fully automated trading system on wide area network connecting Dhaka, Sylhet, Rajshahi, Barisal, and Cox's Bazar based brokers to Chittagong enabling hundreds of thousands of people to invest in the security market.

\section{Regulation of capital market of Bangladesh}

In keeping with the broad thrust of the ongoing programs of economic reform, the mechanism of administrative controls over capital issues has been dismantled and pricing of capital issues is now essentially market determined. That's why in pursuance of the proclamation of the $25^{\text {th }}$ day of march, 1969 read with the provisional constitutional Order, and in exercise of all power enabling him in that behalf, the president is pleased to make and promulgate the Securities and Exchange Ordinance,1969.Under this Ordinance, "no stock exchange shall operate or carry on its functions and no person shall use or utilize ,for the purpose of any transaction or dealing in any security, the facilities or services of a Stock Exchange, unless such Stock Exchange is registered"'(sec:3).In exercise of the powers conferred by section 33 of the securities and Exchange Ordinance, 1969(xvii of 1969), and in supersession of all rules and orders made in this behalf, the government is pleased to make the securities and Exchange Rules 1987,namely:regulation of certain trading in the stock exchange(sec:4a);maintenance of books of account and other documents by stock exchange(sec:7);maintenance of consolidated customers' account(sec:8a);submission of annual report by Stock exchange and by issuers(sec:10,12)etc. Regulation of the capital markets and protection of investor's interest is now primarily the responsibility of Securities and Exchange Commission of Bangladesh (SECB) Act, which was established on $8^{\text {th }}$ June 1993.Under the SECB Act.1993, the chairman and member of the commission are appointed by Government and have overall responsibility to administer securities legislation. The commission is a statutory body and attached to the ministry of finance. The main functions of SECB are such as-regulation the business of the stock exchanges or any other securities market; registering and regulating the business of stock brokers, sub brokers, share transfer agents, merchant bankers and managers of issues, transfer of trust deeds, registrar of an issue, underwriters, portfolio managers, investment advisers and intermediaries in the security market; forms of mutual funds; registering, monitoring and regulating of collective investment scheme including all; monitoring regulating all authorized self regulatory organization in securities market; prohibiting fraudulent and unfair trade practices relating to securities trading in any; promoting investors' education and proving training for intermediaries of the security market; prohibiting insider trading securities; regulation the substantial acquisition 
of shares and takeover of the companies; undertaking investigation and inspection, inquires and audit of issues of dealer of securities; conducting research and publishing information etc[13].

\section{Conclusion}

The authors basically focused on the compliance of corporate governance principles, theories with a special reference to SECB Corporate Governance Guidelines in this study. Securities and Exchange Commission Bangladesh (SECB) has been established to monitor the stock market. The SECB has started to have its presence felt in the stock market. These are all steps in the right direction. However, ministry of Law, Justice and Parliamentary Affairs of Bangladesh government is considering to incorporate corporate governance provisions by amending Companies Act.1994 [14].But much needs to be done. Unfortunately, investors have little confidence in corporate accounting information in Bangladesh [15].Therefore; Business people should cultivate ethical standards, nurture moral values, feel accountability and comply with corporate governance rules in the spirit of the term.

\section{References}

[1] Pandey, I.M. (2006), Financial Management, Ninth Edition p.742

[2] Rossenberg, A. (2002) “An ADB Expert in Discussion Meeting with CSE Listed Companies"p.32

[3] Bhagat S., and Bolton B., (2008), "Corporate Governance and Firm Performance", Journal of Corporate Finance, p.258

[4] OECD (1998), "OECD Principles of Corporate Governance" Printed in Corporate Governance in Banking and Finance, Tata Mcgraw Hill Publishing Company Ltd. New Delhi.

[5] Hawley,J.P. and William A.T.(1996),Corporate Governance in the United States: The risk of Fiduciary Capitalism, Working paper, Saint Mary's College of California, School of Economic and Business Administration.

[6] Donaldson, L., and Davis, J.H. (1994), "Boards and Company Performance-Research Challenges the conventional Wisdom", Corporate Governance: An international Review, Vol.2, no.3 p.151-60

[7] Turbull, S. (1991), Re-inventing Corporations, Human System Management, IOSPress, Vol.10,p.169-86

[8] Gunfest,J.(1990), "Subordination of American Capital",Journal of Financial Economics, V01.27, p.89-114

[9] Sullivan, Arthur; Steven M., Sheffrin (2003), Economics Principles in Action Upper Saddle Rivers: Pearson Prentice Hall.p.238,

[10] Brigham, Eugene F.; Gapenski, Louis C.; Ehrahardt, Michael C., Financial Management, Ninth edition,p.115.

[11] Fabozzi, F.; Modigliani, F.; Ferry, M. (1994), Foundation of Financial Markets and Institutions, Prentice Hall International, London, p.6

[12] Halpern, P.; Westorn, F.; Brigham,E.(1998), Financial Manageriate, Editura Economica,Bucuresti, p.55

[13] M.Zahir, Dr.,Companies and Securities Laws, Revised and Updated Edition.

[14] Draft Code (2004) "Drafts Code of Corporate Governance-Bangladesh" The Bangladesh Accountant, Oct-Dec 2004

[15] Kabir, Md.Humayon (2002), "Corporate Governance in the USA and Japan-A Comparative Analysis", Journal of Business Administration, p.37 